\title{
Hearing Loss Inquiry using Audiometry
}

\author{
S.Prasath, N.Subhalakshmi, T.Manoj Prasath, R.Vasuki
}

\begin{abstract}
The etiology of hearing misfortune is multifactorial which makes the analysis a difficult exercise and frequently an unsolved puzzle. While unadulterated tone audiometry is an obligatory examination, others, for example, research facility and radiology depend on clinical assessment. This current report's on the examination of connection between self-detailed commotion presentation amid relaxation activities and audiological indicators including measured hearing threshold levels (HTL) and tinnitus. The research was conducted by cross sectional survey of 1432 individuals from 11 to 35 years old. Methodology included of a full audiometric assessment including otoscopy, pure tone audiometry (PTA), otoacoustic emission $(\mathrm{OAE})$ and tympanometry, hearing loss investigation, diagnosis, evoked response audiometry radiology, deafness.
\end{abstract}

Keywords-Audiometry,Atoacoustic Emission,Tymapnometry

\section{INTRODUCTION:}

Sensorineural hearing misfortune (SNHL) alludes to hearing debilitation coming about because of natural issue of cochlea or the sound-related nerve and its associations in brainstem. Typical hearing relies upon honesty of the soundrelated pathway and on vascular, hematological, metabolic and endocrine frameworks. An assortment of etiologies have been ensnared (Table 1), and a wide scope of examinations (Table 2) are accessible. Be that as it may, pinpointing the analysis in sensorineural hearing misfortune can be a difficult exercise. In this paper, we endeavor to advance a convention for the examination of sensorineural hearing misfortune.

Media and logical distributions much of the time imply an expanded rate of hearing misfortune through expanded commotion introduction amid recreation exercises especially including uproarious music. A few investigations have revealed huge hearing edge moves in youthful populaces ascribed to unreasonable commotion introduction from the expanding cooperation in high clamor relaxation exercises (1-5). Other distributed work provides reason to feel ambiguous about this presumption (6-8). An ongoing complete audit of the writing around there reasoned that discourse to date has been "ostensibly more theoretical than prove based" and that further more clear, unambiguous data is required (9).

Revised Manuscript Received on July 10, 2019

S.Prasath, Assistant Professor, Department Of Biomedical Engineering, Bharath Institute of Higher Education and Research, Chennai. T.N.India.

N.Subhalakshmi, Assistant Professor, Department Of Biomedical Engineering, Bharath Institute of Higher Education and Research, Chennai. T.N,India.

T.Manoj Prasath, Assistant Professor, Department Of Biomedical Engineering, Bharath Institute of Higher Education and Research, Chennai. T.N,India.

Dr.R.Vasuki, Assistant Professor, Department Of Biomedical Engineering, Bharath Institute of Higher Education and Research, Chennai. T.N,India.
It is acknowledged that long haul clamor introduction wil cause commotion damage (NI) or hearing misfortune (HL) (for example an unadulterated tone edge move). Given adequate introduction, a huge hearing debilitation (HI) may happen (10). Three imperative components add to clamor presentation: the 'normal uproar's (LAeq) over the span of the occasion; the timespan of the occasion itself; and the quantity of occasions altogether[1-6].

While considering non-work and relaxation clamor it must be perceived that as a person's way of life changes so to do their recreation exercises[13-19]. The introduction to commotion from specific exercises will change amid movement from immaturity to adulthood. Subsequently as way of life changes so noises presentation. In this manner as an individual ages their recreation profile changes and their commotion presentation profile additionally changes (11). In this setting the National Acoustic Laboratories (NAL) established a venture called "Pervasiveness hearing misfortune and its relationship to recreation sound presentation" financed by the workplace of Hearing Services, under their Hearing Loss Prevention Program (12) REI 244/0708. The information introduced here is a subset of the bigger examination.

This investigation set out to test the theory: "Is the apparent increment in recreation commotion introduction detrimentally affecting the consultation strength of youthful Australians, as confirm by hearing limit levels?"

\section{MATERIALS AND METHODOLOGY}

\section{Subjects}

An example of the NSW populace somewhere in the range of 11 and 35 years of age was enrolled from different associations including secondary schools, colleges, TAFE Colleges and an assortment of working environments from government and private parts. The main criteria was to be inside the objective age extend[7-11].

Members finished a thorough hearing wellbeing, mentalities and conduct review with a specific accentuation on relaxation support including noteworthy clamor[20-29]. This included yet was not constrained to; participation at move clubs, shows, noisy music occasions; individual stereo use; playing a melodic instrument; investment in a band or symphony; gun use; and engine sports, The review was finished, on paper or on-line, preceding participation at an evaluation arrangement for far reaching audiometric testing, Further inquiries identifying with current hearing wellbeing status, ongoing commotion presentation and learning of hearing wellbeing standards were asked amid the arrangement[30-35]. 
An all out number of $1432(\mathrm{~m}=42 \%, \mathrm{f}=58 \%)$ people gave satisfactory data to have the capacity to add to this investigation. The full subtleties of the limits of this gathering were distributed beforehand (13). No individual motivations were offered, however a humble gift for every member was settled on to the philanthropy of decision of each taking an interest association[36-45]. Associations were enlisted from a different scope of zones including city, more prominent metropolitan and rustic areas trying to incorporate investment from a wide scope of financial and statistic foundations.

\section{Audiometric testing}

Audiometric testing was carried out on-location. The audiometric test conditions met the requirements of international standards for measuring to a minimum $0 \mathrm{~dB}$ HTL with an uncertainty of $+5 \mathrm{~dB}$ (14). This was managed by choosing quietest, appropriate available location at the test site and by use insert earphones covered by a noise excluding headset (15) thus ensuring that the strict requirements for maximum permissible ambient sound pressure levels as stipulated by ISO 8253-1 (14) were met. Ambient noise conditions were sampled throughout the test session and any results obtained during non-complaint conditions were excluded from the analysis.

Audiometric tests included air-conduction audiometry (500, 1000, 2000, 4000, $6000 \& 8000 \mathrm{~Hz})$ and boneconduction audiometry $(500,1000,2000,4000 \mathrm{~Hz})$ if airconduction thresholds were worse than $15 \mathrm{~dB}$ (masked required). Prior to audiometric testing an otoscopic examination was undertaken to exclude occluded ear canals or any other irregularity. All tests were carried out by appropriately qualified, professional audiologists. A comprehensive description of all audiometric tests carried out and detailed hearing threshold levels determined, are presented in detail in a specific report on this aspect of the study (12).

Both distortion product (DPOAE) and transient evoked (TEOAE) were measured. For DPOAE amplitude (two protocols) and signal-to-noise ratio (SNR) parameters were measured in the range $1.5-4 \mathrm{kHz}$, and for TEOAE reproducibility, amplitude and SNR were measure from 1 $4 \mathrm{kHz}$.

\section{Estimation of life-time noise exposure}

NAL has investigated noise exposure over many years and has developed specific research tools to gather information on the historic noise exposure of individuals and groups (16). These measures provide data used to estimate cumulative life time noise exposure, by extending the techniques described in International Standard ISO 1999 for calculating the daily A-weighted sound exposure, EA, 8h (10). The ISO technique is extended by summing multiple exposures, from multiple sources over an extended period. This includes all significant exposures over a life time. Cumulative noise exposure is presented in the units of Pascal provides the value hours ( $\mathrm{Pa} 2 \mathrm{~h})$ rather than Pascal squared seconds ( $\mathrm{Pa} 2 \mathrm{~s})$ as is used for EA,8h. This procedure provides the value of an eight hour continuous A-weighted noise exposure of $85 \mathrm{~dB}$ being $1.01 \mathrm{~Pa} 2 \mathrm{~h}$ rather than 3.64 kpa2s.

The value 1.01 $\mathrm{Pa} 2 \mathrm{~h}$ represents a significant value as it is the define action level, or Exposure Standard, for exposure to continuous workplace noise in Australia and New Zealand (17). As such it conveniently represents a recognisable indication of the relative risk of hearing loss, or noise injury, for the noise exposed individual. Furthermore, the figure of $1.01 \mathrm{~Pa} 2 \mathrm{~h}$ represents what can be considered as an "acceptable daily exposure". This does not represent zero risk, rather it represents what is agreed as a generally acceptable exposure risk. This concept provides the basis for the following discussions.

Accumulated information on typical noise exposure during non-work and leisure activities, particularly those considered 'high risk', are used when estimating individual noise exposure (18). An activity is considered to be high risk when it presents a noise risk an order of magnitude greater than that provided by exposure to the recommended Exposure Standard of 1.01 Pa2h.

\section{What is a 'safe' as opposed to 'acceptable' noise exposure level?}

Having established what can be considered as an acceptable level of daily exposure, it is possible to propose a 'safe' or 'low risk' exposure level. If the acceptable risk is taken to be $1 \mathrm{~Pa} 2 \mathrm{~h} /$ day then a negligible risk of one tenth of this, $0.10 \mathrm{~Pa} 2 \mathrm{~h}$, could be proposed as posing a relatively negligible risk. This is equivalent to a daily exposure, LAeq, $8 \mathrm{~h}$, of $75 \mathrm{~dB}$.

\section{Data analysis and Ethics}

All statistical calculation were carried out using Microsoft Excel 2010 and/or Statistica Version 10 (Dell P/L). Ethics approval was provided by the Australian Hearing Human Research Ethics committee and with respect to work in schools, the NSW Department of Education and Training Student Engagement and Program Evaluation Bureau.

\section{RESULT AND DISCUSSION}

Nothing that the aim of this study was to examine the relationship between leisure noise exposure and hearing health, the initial analyses of the data were concerned with a comprehensive examination of participant hearing thresholds and/or hearing loss with respect to their cumulative life time noise exposure. Numerous attempts were made, using multiple regression analysis, to relate cumulative exposure to individual threshold levels and combination of threshold levels. This included using thresholds at individual frequencies and the averages of several combinations of threshold levels at selected frequencies. There were no statistically significant correlations found between life time cumulative noise exposure and hearing thresholds.

The information obtained from participants indicates there is an extremely wide variation of noise exposure across the community and that the exposure levels may be expected to produce a permanent hearing threshold shift (PTS) in many individuals. Cumulative exposure ranged 
from relatively negligible values up to a maximum of 86.7 $\mathrm{kPa} 2 \mathrm{~h}$ with an exposure rate of $2.94 \mathrm{kPa} 2 \mathrm{~h}$ per year. This is, far beyond the expected occupational exposure for an equivalent individual working in industry if exposed to a level at the Exposure Standard of $1 \mathrm{~Pa} 2 \mathrm{~h}$ per day for 220 working days per year for forty years, who only receives 8.8 $\mathrm{kPa} 2 \mathrm{~h}$.

As is clearly shown from Tables 1 and 3 there is no demonstrated significant hearing loss across the sampled populations. That is there is no evidence of a shift in the noise exposed population where it would be expected on the basis of previous reports (1), (2), (3) and ISO 1999 (10). The threshold distributions down to the 0.90 fractile can be considered as clinically insignificant or unremarkable down to the poorest value of $15 \mathrm{~dB}$ across all frequencies. It should be noted that currently there are no recognised normative threshold levels published for any large scale populations younger than 18 years old. The closest applicable set of reference HTLs come from International Standard "ISO 7029 which commence at age 18 years (20). The normative levels presented in Table 1 agree well with those presented in ISO 7029 taking into consideration that in the method under discussion here the minimum HTL measured was $0 \mathrm{~dB}$ due to constraints of field testing (19).

It is important to emphasize that these results do not suggest that frequent exposure to loud sound does not and will not affect hearing thresholds, particularly if the existence of International Standard "ISO 1999 Acoustics Estimation of noise - induced hearing loss" (10).

In interpreting these findings, it is also important to consider that there is evidence that individuals display varying susceptibility to noise exposure in terms of noise injury and hearing loss (10), (22). It may be possible that the variable characteristics of noise in leisure situations produce different outcomes when compared to the more consistent characteristics of workplace noise (23). The range of thresholds (presented in Table 3) associated with the range of exposures for the most highly exposed participants may be indicative of varying individual susceptibility as predicted by ISO 1999.

The results in the current work were closely mirrored in an earlier, on-line survey of exposure to loud leisure noise activities conducted by the National Acoustic Laboratories and the ABC, 'Sound Check Australia' (22). In this study individuals were asked about their participation in highnoise leisure activities and symptoms of hearing damage. Tinnitus question responses indicated experience of tinnitus at: 30\% 'never'; 37\% 'occasionally'; 18\% 'sometimes'; 4\% 'often'; and 2\% 'always'. There were $9 \%$ of survey respondents who selected the 'unsure' category for this question and were excluded from further analysis. If the 'occasionally' and 'sometimes' categories are combined these results closely mirror the current study. Both this study and the current, in fact, represent the same overall Australian population so close agreement is to be expected.

There is a growing body of evidence showing that central auditory processing is slower, weaker and localized differently in the noise exposed human brain. Recent research suggests that noise exposed individuals' auditory skills are adversely affected prior to the clinical measurement of a hearing loss (24), (25). This could be the basis of the frequently made comment 'I can hear OK, but sometimes have trouble following conversation in background noise'.

\section{CONCLUSIONS:}

The results her demonstrated that there is no evidence of changes in hearing thresholds or otoacoustic emissions due to noise exposure from leisure activities. However, the experience of tinnitus has been clearly demonstrated to be widespread in the young adult population and there is a strong relation to cumulative noise exposure from noisy activities. Improved, personalized hearing health education messages could draw attention to the experience of tinnitus after early episodes of noise exposure, utilizing this awareness $\mathrm{s}$ a facilitator for future personal preventative action by young adults before higher levels of noise exposure are reached.

\section{REFERENCES}

1. Lemkens N, Vermeire K, Brokx JP, Fransen E, Van Camp G, Van De Heyning PH. Interpretation of pure-tone thresholds in sensorineural hearing loss (SNHL): A review of measurements variability and age-specific references. Acta Otorhinolaryngol Belg 2002; 56 (4): 341-52.

2. Reiss M, Reiss G. Differential diagnosis of unilateral hearing loss. Praxis 2000 Feb 3; 89 (6) : 241-47.

3. Mahillon V, Saussez S, Gerard JM, Chantrain G, Thill MP. Diagnostic management of unilateral sensorineural hearing loss in adults. Rev Med Brux 2003 Feb; 24(1): 15-19.

4. Ruth RA, Lambert PR, Ferraro JA. Electrocochleography: Methods and clinical applications. Am J Otol 1998; 9; 1.

5. Lajtman Z, Borciae V, Markov D, Popoviae J, Vincelj J, Krpan D. Clinical interpretation of brainstem evoked response audiometry abnormalities in cochlear pathology. Acta Med Croatica 1999; 53 (3): 119-23.

6. Shargorodsky J, Curhan SG, Curhan GC, Eavy, R. "Change in prevalene of hearing loss in US adolescents", Journal of the American Medical Association, 304, 772-778, (2010).

7. Cone BK, Wake M, Tobin S, Poulakis Z, Rickards FW "Slight-mild sensorineural hearing loss in children: Audiometric, clinical, and risk factor profiles", Ear \& hearing, 31, 202-212,(2010).

8. LePrell CG, Hensley BN, Cmpbell KCM, Hall JW, Guire K "Evidence of hearing loss in a 'normally-hearing' collegestudent population", International Journal of Audiology, 50, S2-S31, (2011).

9. Names J. "Teen hearing loss study goes viral, experts uncover the facts" The Hearing Journal, 64, 19-24, (2011).

10. Brande V. "The teen hearing loss 'state of emergency", editorial in The Hearing Journal, 64: 4, (2011).

11. Schlauch RS. "Noise-induced hearing loss in teenagers", Acoustics Today, 14-18, (2013).

12. ISO 1999: 2013 Acoustics - Estimation of noise-induced hearing loss, International Organisation for Standardisation, Geneva, 2013.

13. Carter L, Williams W, Black D \& Bundy A. "The leisurenoise dilemma: hearing loss or hearsay? What does the literature tell us?", Ear \& Hearing, 35, 491-505, (2014).

14. Fisher M, Williams W. "Reduced conditions on ambient noise levels for in-situ audiometric testing", Technical Note, Acoustics Australia, 41, 232-233, (2013).

15. Williams W, Carter L, Seeto M. "Hearing thresholds for a population of 11 to 35 year old Australian females and 
males", 53, 289-293, (2014).

16. Schlauch RS, Carney E. "The challenge of detecting minimal hearing loss in audiometric surveys", American Journal of Audiology, 21, 106-119, (2012).

17. Carter L, Williams W, Seeto M. "Otoacoustic emission findings of an Australian cross-sectional hearing study", International Journal of Audiology, in press, (2015).

18. ISO 7029: 2000 Acoustics - Statistical distribution of hearing thresholds as a function of age, International Organisation for Standardisation, second edition, Geneva, 2000.

19. Kumar AU, Ameenudin S, Sangamanath AV. "Temporal and speech processing skills in normal hearing individuals exposed to occupational noise", Noise \& Health, 14, 100-105, (2012).

20. Terk AR, Kveton JF. Clinical evaluation of hearing loss 17482.

21. Noel PE, Ramsey MJ, Amedee RG. Otoacoustic emissions: An emerging diagnostic tool. J La State Med Soc Apr 1995; 147 (4) : 125-30.

22. Lejeune JM, Charachon R. New immunobiological tests in the investigation of Meniere's disease and sensorineural hearing loss. Acta Otolaryngol 1992; 112 (2) : 174-79.

23. American Academy of Pediarics. Year 2000 position statement Principles and guidelines for early hearing detection. Pediatrics 2000; 106: 798-817.

24. Berlin CI, Morlet T, Hood LJ. Auditory neuropathy/dyssynchrony: Diagnosis and management. Pediatr Clin North Am 2003; 331-40.

25. Schuknecht B, Graetz K. Radiologic assessment of maxillofacial, mandibular, and skull base trauma. Eur Radiol 2005 Mar; 15 (3): 560-68.

26. Sharmila S., Jeyanthi Rebecca L., Das M.P.,Production of Biodiesel from Chaetomorpha antennina and Gracilaria corticata,Journal of Chemical and Pharmaceutical Research,V-4,I-11,PP-4870-4874,Y-2012

27. Aarthi C., Ramesh Babu P.B.,Anti-cancer activity of Phyllanthus reticulatus on colon cancer cell line, International Journal of Civil Engineering and Technology, V-8,I-1,PP-943947,Y-2017

28. Sharmila S., Jeyanthi Rebecca L., Das M.P., Saduzzaman M.,Isolation and partial purification of protease from plant leaves,Journal of Chemical and Pharmaceutical Research, V4,I-8,PP-3808-3812,Y-2012

29. Jayalakshmi T., Krishnamoorthy P., Ramesh Babu P.B., Vidhya B.,Production, purification and Biochemical characterization of alkaline Fibrinolytic enzyme from Bacillus Pharmaceutical Research,V-4,I-12,PP-5027-5031,Y-2012

30. Jeyanthi Rebecca L., Susithra G., Sharmila S., Das M.P.,Isolation and screening of chitinase producing Serratia marcescens from soil,Journal of Chemical and Pharmaceutical Research,V-5,I-2,PP-192-195,Y-2013

31. Aarthi C., Ramesh Babu P.B.,Antimicrobial and antioxidant activity of phyllanthus niruri,International Journal of Pharmacy and Technology,V-8,I-2,PP-14701-14707,Y-2016

32. Anbuselvi S., Jeyanthi Rebecca L., Sathish Kumar M., Senthilvelan T.,GC-MS study of phytochemicals in black gram using two different organic manures, Journal of Chemical and Pharmaceutical Research,V-4,I-2,PP-1246$1250, \mathrm{Y}-2012$

33. Soniyapriyadharishni A.K., Ramesh Babu P.B.,Data mining strategies for identification of HNF4A MODY gene using gene prioritize tool,Journal of Chemical and Pharmaceutical Research,V-6,I-3,PP-1126-1133,Y-2014

34. Sharmila S., Jeyanthi Rebecca L., Naveen Chandran P., Kowsalya E., Dutta H., Ray S., Kripanand N.R.,Extraction of biofuel from seaweed and analyse its engine performance,International Journal of Pharmacy and Technology, V-7,I-2,PP-8870-8875,Y-2015

35. Sharmila S., Jeyanthi Rebecca L., Saduzzaman M.,Biodegradation of domestic effluent using different subtilisstrain-GBRC1,Journal of Chemical and

solvent extracts of Murraya koenigii,Journal of Chemical and Pharmaceutical Research,V-5,I-2,PP-279-282,Y-2013

36. Jeyanthi Rebecca L., Sharmila S., Das M.P., Seshiah C.,Extraction and purification of carotenoids from vegetables,Journal of Chemical and Pharmaceutical Research,V-6,I-4,PP-594-598,Y-2014

37. Krishnamoorthy P., Praveen Kumar P.K., Ramesh Babu P.B.,Community based evaluation of phenylthiocarbamide (PTC) sensitivity and Dermatoglyphics as a genetic marker in Tamilnadu, India,International Journal of Pharmacy and Technology, V-5,I-3,PP-5705-5712,Y-2013

38. Sharmila S., Jeyanthi Rebecca L.,GC-MS Analysis of esters of fatty acid present in biodiesel produced from Cladophora vagabunda,Journal of Chemical and Pharmaceutical Research,V-4,I-11,PP-4883-4887,Y-2012

39. Sinha S., Rajasulochana P., Ramesh Babu P.B., Krishnamoorthy P.,Comparative modelling of shikimate kinase $(\mathrm{M} \mathrm{Tb})$ and molecular docking studies of its known inhibitors, Research Journal of Pharmaceutical, Biological and Chemical Sciences, V-4,I-3,PP-715-720,Y-2013

40. Jeyanthi Rebecca L., Dhanalakshmi V., Sharmila S.,Effect of the extract of Ulva sp on pathogenic microorganisms,Journal of Chemical and Pharmaceutical Research,V-4,I-11,PP-48754878,Y-2012

41. Sharmila S., Jeyanthi Rebecca J.,A comparative study on the degradation of leather industry effluent by Marine algae,International Journal of Pharmaceutical Sciences Review and Research,V-25,I-2,PP-46-50,Y-2014

42. Ramesh Babu P.B., Krishnamoorthy P., Gayathri G.,Identification of drug target site on citrate synthase of food pathogen - Campylobacter jejuni,Research Journal of Pharmaceutical, Biological and Chemical Sciences, V-4,I1,PP-618-623,Y-2013

43. Sharmila S., Rebecca Jeyanthi L., Saduzzaman M.,Biodegradation of tannery effluent using Prosopis juliflora,International Journal of ChemTech Research, V-5,I5,PP-2186-2192,Y-2013

44. Kumar S., Das M.P., Jeyanthi Rebecca L., Sharmila S.,Isolation and identification of LDPE degrading fungi from municipal solid waste,Journal of Chemical and Pharmaceutical Research,V-5,I-3,PP-78-81,Y-2013

45. Das M.P., Jeyanthi Rebecca L., Sharmila S., Anu, Banerjee A., Kumar D.,Identification and optimization of cultural conditions for chitinase production by Bacillus amyloliquefaciens SM3,Journal of Chemical and Pharmaceutical Research,V-4,I-11,PP-4816-4821,Y-2012

46. Ramesh Babu P.B., Krishnamoorthy P., Rekha R.,Develoment of comprehensive online database model for genes responsible for asthma,Research Journal of Pharmaceutical, Biological and Chemical Sciences, V-4,I-1,PP-865-871,Y-2013

47. Devi M., Jeyanthi Rebecca L., Sumathy S.,Bactericidal activity of the lactic acid bacteria Lactobacillus delbreukii,Journal of Chemical and Pharmaceutical Research,V-5,I-2,PP-176-180,Y-2013

48. Ramesh Babu P.B., Miller T.L., Chidekel A., Shaffer T.H.,Clara cell protein mediates secretion of proteins, IL-8 and IL-6 in human airway epithelial cell line Calu-3 exposed to hyperoxia,Journal of Chemical and Pharmaceutical Research,V-4,I-6,PP-3164-3170,Y-2012

49. Bhuvaneswari B., Hari R., Vasuki R., Suguna,Antioxidant and antihepatotoxic activities of ethanolic extract of Solanum torvum,Asian Journal of Pharmaceutical and Clinical Research,V-5,I-SUPPL. 3,PP-147-150,Y-2012

50. Abraham Samuel F., Mohan V., Jeyanthi Rebecca L.,Physicochemical and heavy metal analysis of sugar mill effluent,Journal of Chemical and Pharmaceutical Research,V6,I-4,PP-585-587,Y-2014 
51. Narayani P.C., Anbu J., Vasuki R., Hari R.,Invitro and invivo anti-arthritic activity of combined ethanolic extracts of Calotropis gigantea and Cardiospermum halicacabum in Wistar rats,Journal of Natural Remedies, V-14,I-1,PP-5866,Y-2014

52. Paul Das M., Jeyanthi Rebecca L., Sharmila S., Anu, Banerjee A., Kumar D.,Identification and optimization of cultural conditions for chitinase production by Bacillus amyloliquefaciens SM3,Journal of Chemical and Pharmaceutical Research,V-4,I-12,PP-4969-4974,Y-2012

53. Vasuki R., Hari R., Pandian S., Arumugam G.,Hepatoprotective action of ethanolic extracts of eclipta alba and piper longum linn and their combination on CCL 4 induced hepatotoxicity in rats,International Journal of Pharmacy and Pharmaceutical Sciences,V-4,I-SUPPL.1,PP455-459, Y-2012

54. Saduzaman M., Sharmila S., Jeyanthi Rebecca L.,Efficacy of leaf extract of Moringa oleifera in treating domestic effluent,Journal of Chemical and Pharmaceutical Research,V5,I-2,PP-139-143,Y-2013

55. Senthil Kumar K., Vasuki R., Priya R.,Green synthesis, pegylation of silver nano herbal complexand study of its antimutagenicity activity,International Journal of Pharmacy and Technology, V-8,I-2,PP-12130-12143,Y-2016

56. Srivastava S., Seethalakshmi I., Jeyanthi Rebecca L.,Antimicrobial and antioxidant properties of cissus quandrangularis,Journal of Chemical and Pharmaceutical Research,V-5,I-5,PP-131-134,Y-2013

57. Gireeshan M.G., Vasuki R., Krishnakumar T.,High power production from elephantâ $€^{\mathrm{TM}_{\mathrm{S}}}$ urine,International Journal of Pharmacy and Technology,V-6,I-2,PP-6714-6718,Y-2014

58. Jeyanthi Rebecca L., Dhanalakshmi V., Sharmila S., Das M.P.,In vitro antimicrobial activity of Gracilaria SP and Enteromorpha SP,Research Journal of Pharmaceutical, Biological and Chemical Sciences, V-4,I-1,PP-693-697, Y2013

59. Jeyanthi Rebecca L., Dhanalakshmi V., Thomas T.,A comparison between the effects of three algal extracts against pathogenic bacteria,Journal of Chemical and Pharmaceutical Research,V-4,I-11,PP-4859-4863,Y-2012 